Copyright ( $) 2020$ University of Bucharest Printed in Romania. All rights reserved

ISSN print: $1224-5984$

ISSN online: $2248-3942$
Rom Biotechnol Lett. 2020; 25(3): 1601-1606 doi: $10.25083 / \mathrm{rbl} / 25.3 / 1601.1606$

Received for publication, September, 27, 2017

Accepted, October, 25, 2017

Original paper

\title{
The level of polycyclic aromatic hydrocarbons (PAHs) from pork meat depending on the heat treatment applied
}

\author{
AURELIA COROIAN ${ }^{1}$, VIOARA MIREŞAN ${ }^{1}$, CRISTIAN OVIDIU COROIAN ${ }^{1 *}$, CAMELIA \\ RĂDUCU ${ }^{1}$, DANIEL COCAN ${ }^{1}$, LUISA ANDRONIE ${ }^{1}$, ANCA NAGHIU ${ }^{2}$, ADINA LIA \\ LONGODOR $^{1}$, RADU CONSTANTINESCU ${ }^{1 *}$, ZAMFIR MARCHIŞ ${ }^{1}$
}

${ }^{1}$ University of Agricultural Sciences and Veterinary Medicine Cluj-Napoca, Faculty of Animal Science and Biotehnology, Mănăştur Str. 3-5, 400272, Cluj-Napoca, Romania

${ }^{2}$ Research Institute for Analytical Instrumentation (ICIA) Cluj-Napoca, Str. Donath 67, 400293, Cluj-Napoca, România

\begin{abstract}
PAHs from pork meat, ham, shoulder and bacon were investigated, after different thermal processes were applied. The samples were subjected to boiling, roasting and curing processes. Phenanthrene had the highest value $\left(35.76 \mu \mathrm{g} \mathrm{kg}^{-1}\right)$ in ham, when curing process was applied, while the lowest value $\left(29.25 \mu \mathrm{g} \mathrm{kg}^{-1}\right)$ was obtained when boiling process was applied. The same trend was observed for pork meat, ham and bacon. In bacon, benzo(a)pyrene had the highest value $\left(0.67 \mu \mathrm{g} \mathrm{kg}^{-1}\right)$ for curing process, followed by roasting $\left(0.53 \mu \mathrm{g} \mathrm{kg}^{-1}\right)$ and boiling $\left(0.51 \mu \mathrm{g} \mathrm{kg}^{-1}\right)$ process, respectively. By others PAHs (naphthalene, acenaphthene, flourene, anthracene, fluoranthene, pyrene, benzo(k)fluoranthene) the highest values were observed by curing process compared to roasting and boiling processes.
\end{abstract}

Keywords PAHs, pork meat, boiling, roasting, curing.

To cite this article: COROIAN A, MIREŞAN V, COROIAN CO, RĂDUCU C, COCAN D, ANDRONIE L, NAGHIU A, LONGODOR AL, CONSTANTINESCU R, MARCHIS Z Z. The level of polycyclic aromatic hydrocarbons (PAHs) from pork meat depending on the heat treatment applied. Rom Biotechnol Lett. 2020; 25(3): 1601-1606. DOI: $10.25083 / \mathrm{rbl} / 25.3 / 1601.1606$

*Corresponding author: CRISTIAN OVIDIU COROIAN, RADU CONSTANTINESCU, University of Agricultural Sciences and Veterinary Medicine Cluj-Napoca, Faculty of Animal Science and Biotehnology, Mănăştur Str. 3-5, 400272, Cluj-Napoca, Romania E-mail: cristian.coroian@ usamvcluj.ro $\quad$ radu.constantinescu@ usamvcluj.ro 


\section{Introduction}

In terms of nutrition, the quality of meat is given by its content in proteins, lipids, vitamins and mineral salts. Meat contains high amounts of methionine, lysine and low amounts of leucine, isoleucine and valine. Meat has low level in calcium compared to milk and cheese. It is a high source of iron, necessary for the human body. It also has a high content of vitamins in group B and vitamin PP. Meat composition is given by state of animal fattening, species, race, age, type of diet, type of fattening and breeding area (VINTILĂ [1]; COROIAN [2]; SUHAROSCHI [3]; RĂDUCU [4]). The chemical composition of meat is greatly influenced by species from which the meat comes and especially by thermal processes applied. Meat is a staple food for human consumption due to its nutritional value, superior digestibility and good dietary-culinary quality. The proportion of different tissues in meat composition varies depend on race, age, sex, and fattening status (OȚEL [5]; BULANCEA \& al [6]).

According to literature, polycyclic aromatic hydrocarbons (PAHs) of curing products are greatly varying. This discrepancy appears due to the difference that exists between curing processes (wood type and composition, oxygen accessibility, cured temperature generated and cured type), chemical composition of cured product, fat content and water content. PAHs are a large group of organic compounds which are formed from two or more combined aromatic nuclei (GRIMMER [7]; NIELSEN \& al [8]; SUCHAROSCHI [3]). During pyrolysis processes or incomplete combustion of organic matter, hundreds of different PAHs can be formed and released into the environment (FETZER [9]).

Applying food processing (curing, roasting, baking, cooking), PAHs are formed in food. There are a lot of studies carried out with laboratory animals, which demonstrate the severe carcinogenic effect of PAHs (STUMPEVIKSNA \& al [10]; EC 2005 [11]). From a chemical point of view, PAHs can also be obtained by isolating certain compounds. Up to now, over five hundred PAHs have been isolated, but only a small proportion of these have been evaluated in a toxicological aspect (BANU [12]; LASLO [13]; SHIBAMOTO [14]).

People are daily in contact with polycyclic aromatic hydrocarbons through the consumption of food, water but also through the air that people breathing. Polycyclic aromatic hydrocarbons also occur during industrial processes such as bitumen production, which is necessary for asphalt and mining PAHs get into the air, water, soil and contaminates them through: burning wood and gas, which is necessary to heat homes and burning of plant residues in agriculture (SKUPINSKA [15]).

Also, contamination with polycyclic aromatic hydrocarbons occurs due to other human activities such as: incinerators use in urban areas near homes, metallurgical plants, bakeries, plastic factories, smelters and tobacco factories. PAHs can contaminate soils and surface waters through the atmospheric precipitation that transports PAHs from the air, and deposits them on their surface. Moreover, urban spills and spills of oil or gasoline can cause contamination with polycyclic aromatic hydrocarbons (LEWTAS [16]). A positive aspect, considered by researchers, is that nitro-PAHs occur in extremely low concentrations in diet of consumers (PHILLIPS [17]). Compounds considered toxic due to the high carcinogenic effect are presented in water, air, soil, food and they are in direct contact with main food sources (IARC [18]; EFSA [19]). In recent years, the research of the presence of these compounds in food has greatly developed. It is desirable to use the most sensitive methods in order to detect toxic compounds presence and to avoid the consumption of foods which contain high levels of these compounds (HOWARD [20]). Tea, roasted peanuts, coffee, refined oil, cereals, vegetables and many other foods contain PAHs. Some crops such as: wheat, rye, linden can absorb PAHs through water, air and soil (GRIMMER [7]; MENZIE [21]; SHABAD [22]; IARC [23]). Cooking meat on grill or charcoal, wood or other combustion increases PAHs concentration (PHILLIPS [17]). Thus, it is preferable to avoid direct contact of the meat with the flames of the grill, and cook it with a lower fat content at the grill. Cooking temperature should be low and applied over a long period of time. In this conditions, the PAH content in food can be significantly reduced (JÄGERSTAD \& SKOG [24]; SUHAROSCHI [3]). Certain derivatives of PAHs are biologically active compounds, these compounds are capable to produce mutations in mammalian cells, bacteria, bacteriophages and at the same time can produce malignant transformations in cells, and for experimental animals can cause cancer. The hypothesis issued to explain the carcinogenic action of PAHs is related to interaction of those mutagenic substances with nucleic acids, which result in certain changes in DNA structure and genetic information of cell (SUHAROSCHI [3]). Studies realized with laboratory animals have shown that some polycyclic aromatic hydrocarbons have a carcinogenic effect (PÖHLMANN \& al [25]).

After numerous research studies with laboratory animals, carcinogenic effects of PAHs were observed in the lungs, bladder, liver, stomach and skin level. Animal studies have shown that some PAHs affect the immune system and produce unwanted effects on the reproductive system, neurological system and developmental effects the development of cancer in the intestines, prostate, pancreas after high consumption of roasted meat. Cancer development at the level of intestines, prostate and pancreas is produced after consuming high consumption of roasted meat (DASGUPTA [26]; SZCZEKLIK [27]; ZHAO [28]; NORAT [29]; KNUTSEN [30]). PAHs have a different content, depending on curing process (industrial or traditional) and the type of cured meat. The highest content of PAHs is for samples exposed directly to smoking source (CIECIERSKA \& OBIEDZIŃSKI [31]). The purpose of 
this paper was to evaluate the level of PAHs after different thermal processes (boiling, roasting, curing) were applied for pork meat, shoulders, ham and bacon.

\section{Materials and Methods}

\section{Samples analyzed}

Five samples of each product pork meat, shoulders, ham and bacon were taken. These samples had undergone boiling, roasting and curing. The cured process had been traditionally done. The cured process was done in the morning and evening, with intervals of 8 hours between the stages, for a period of three days. For cured process wood beech was used. This type of wood gave for meat a pleasant flavour and a brown colour. The product ventilation was performed after each curing step (this step is necessary in order to improve the taste and aroma of the product).

\section{Analysis of PAHs}

Analysis of PAHs was realized by the chromatographic method, using the Perkin-Elmer HPLC apparatus. The wavelength range is: $200-850 \mathrm{~nm}$; Emission of 250-900 nm. Chromatographic columns used: Zorbax Eclipse PAH; Agilent Technologies manufacturer, with column sizes $4.6 \times 150 \mathrm{~mm}$, diameter, $5 \mu \mathrm{m}$. Mobile phase in gradient system: acetonitrile and ultra-pure water. $10 \mathrm{~g}$ sample was collected, which was homogenized, after that $50 \mathrm{ml}$ of $0.4 \mathrm{M} \mathrm{KOH}$ solution in ethanol and water was added in a 9:1 ratio for saponification. The latter procedure was performed in an ultrasonic bath for 30 minutes at $60^{\circ} \mathrm{C}$. After 30 minutes, sodium sulphate was added to the sample and then samples were filtered on filter paper. The product obtained was extracted twice with $15 \mathrm{ml}$ of cyclohexane The supernatant was purified on a Florisil column and, then evaporated to dryness under a continuous nitrogen atmosphere. Prior to injection, samples were diluted with $1 \mathrm{ml}$ of acetonitrile, filtered on $0.45 \mu \mathrm{m}$ cartridges.

\section{Statistical analysis}

The normal distribution of the values for each hydrocarbon (naphthalene, acenaphthene, flourene, phenanthrene, anthracene, fluoranthene, pyrene, benzo(k)fluoranthene, benzo(a)pyrene, was verified using the Shapiro-Wilk test. When necessary, in order to fulfil the assumption of normality, data were log transformed prior to analysis. The average for each PAHs was examined using data from five repetitions with an ANOVA model (JMP version 12, SAS Institute, USA) that included terms for different processes (boiling, roasting and curing) that were applied for each products analized (pork meat, shoulders, ham and bacon). Significant differences among treatment means were further examined using Tukey's multiple range test at the 0.05 probability level. A p value of 0.05 was used as the threshold for statistical significance.

\section{Results and Discussion}

The average for each hydrocarbon and the main processes that affect them are reported in Table 1. Products analyzed for all hydrocarbons had the highest values when curing process was applied compared to roasting and boiling processes (Table 1). Moreover, the majority of hydrocarbon (with the exception of: benzo(k)fluoranthene (ham and shoulders) and naphthalene (shoulders) were affected significantly $(\mathrm{P}>0.05)$ by boiling, roasting and curing processes (Table 1 ).

In case of pork meat, phenanthrene had the highest values compared to other hydrocarbons, when different thermal processes were applied (Table 1). The curing process registered the highest values $\left(35.52 \pm 1.12 \mu \mathrm{g} \mathrm{kg}^{-1}\right)$, followed by roasting process $\left(32.36 \pm 1.49 \mu \mathrm{g} \mathrm{kg}^{-1}\right)$ and boiling process $\left(26.90 \pm 1.07 \mu \mathrm{g} \mathrm{kg}^{-1}\right)$, respectively. The lowest values were registred for benzo(k)fluoranthene and benzo(a)pyrene (Table 1).

Benzo(a)pyrene is considered a toxic hydrocarbon (IARC [23]). In the present study, in the case of pork meat, the values (for boiling process $\left(0.48 \pm 0.03 \mu \mathrm{g} \mathrm{kg}^{-1}\right)$ and curing process $\left(0.62 \pm 0.07 \mu \mathrm{g} \mathrm{kg}^{-1}\right)$ obtained for benzo(a)pyrene was below the limit permitted by the legislation in force for benzo(a)pyrene. Similar results were observed by CIECIERSKA \& OBIEDZIŃSKI [31], who reported that benzo(a)pyrene was present regardless that the method of cringing used, but in a lower amount than the maximum permitted by the European Commission $\left(5 \mu \mathrm{g} \mathrm{kg}^{-1}\right)$. The amount of benzo(a)pyrene detected in meat products (to the surface) analyzed was $0.37 \mu \mathrm{g} \mathrm{kg}^{-1}$ and in the interior of the product was $0.28 \mu \mathrm{g} \mathrm{kg}^{-1}$ in the case of industrial cure, while in traditional curing, the amount of benzo(a)pyrene was at outside of $0.43 \mu \mathrm{g} \mathrm{kg}^{-1}$, and those from within $0.27 \mu \mathrm{g} \mathrm{kg}^{-1}$ (CIECIERSKA \& OBIEDZIŃSKI [31]).

All PAHs had the lowest average values after boiling, followed by roasting process, while the highest values were registeredforcuring process (Table 1).

Comparing the mean values for naphthalene, anthracene, fluoranthene, benzo(a)pyrene between ham and pork meat, we observed that pork meat had the lowest values (Table 1). In the case of ham, the highest average values for PAHs were found when curing process was applied, while the lowest average values was found for boiling process.

The anatomical portion has influences about how PAHs are assimilated. When applied boiling process, naphthalene had the lowest value $\left(6.81 \pm 0.39 \mu \mathrm{g} \mathrm{kg}^{-1}\right)$ for shoulders, while the highest value $\left(9.79 \pm 00.38 \mu \mathrm{g} \mathrm{kg}^{-1}\right)$ was found for ham (Table 1). When applied curing process from both of ham and shoulders, naphthaleneregistered high value (Table 1). Similar studies have been conducted by DJINOVIC \& al [32]; SILVA \& al [33]; CHEN \& al [34]; HITZEL \& al [35]; OLATUNJI \& al [36]; ABDUL et al [37].

When applied boiling process, naphthalene had the highest value $\left(9.78 \pm 0.38 \mu \mathrm{g} \mathrm{kg}^{-1}\right)$ for jam, while the lowest value $\left(6.81 \pm 0.39 \mu \mathrm{g} \mathrm{kg}^{-1}\right)$ was found for shoulder. When applied curing process, naphthalene had the highest value $\left(13.18 \pm 0.42 \mu \mathrm{g} \mathrm{kg}^{-1}\right)$ for bacon, while the lowest value $\left(10.69 \pm 0.92 \mu \mathrm{g} \mathrm{kg}^{-1}\right)$ was found for shoulder. In the present study, it is possible to observe that naphthalene depend on: the anatomical propensity, composition of the product, but also the thermal process applied. 
Table 1. Pork meat, ham, shoulders and bacon after boiling, roasting and smoking

\begin{tabular}{|c|c|c|c|c|}
\hline \multicolumn{5}{|c|}{ Pork meat } \\
\hline PAH $\left(\mu \mathrm{g} \cdot \mathrm{kg}^{-1}\right)$ & Boiling & Roasting & Curing & Significance \\
\hline Naphthalene & $7.68 \pm 0.95^{\mathrm{c}}$ & $9.51 \pm 0.66^{b}$ & $11.39 \pm 0.89^{\mathrm{a}}$ & $*$ \\
\hline Acenaphthene & $5.38 \pm 0.58^{\mathrm{c}}$ & $7.35 \pm 0.28^{\mathrm{b}}$ & $12.74 \pm 0.56^{\mathrm{a}}$ & $*$ \\
\hline Flourene & $7.85 \pm 0.46^{\mathrm{c}}$ & $9.21 \pm 0.38^{\mathrm{b}}$ & $10.71 \pm 0.60^{\mathrm{a}}$ & $*$ \\
\hline Phenanthrene & $26.90 \pm 1.07^{\mathrm{c}}$ & $32.36 \pm 1.49^{\mathrm{b}}$ & $35.52 \pm 1.12^{\mathrm{a}}$ & $*$ \\
\hline Anthracene & $0.58 \pm 0.07^{\mathrm{b}}$ & $0.89 \pm 0.06^{\mathrm{a}}$ & $0.93 \pm 0.07^{\mathrm{a}}$ & $*$ \\
\hline Fluoranthene & $3.98 \pm 0.06^{\mathrm{c}}$ & $4.90 \pm 0.09^{\mathrm{b}}$ & $5.24 \pm 0.28^{\mathrm{a}}$ & $*$ \\
\hline Pyrene & $1.60 \pm 0.12^{\mathrm{c}}$ & $2.33 \pm 0.32^{\mathrm{b}}$ & $2.62 \pm 0.12^{\mathrm{a}}$ & $*$ \\
\hline Benzo(k)fluoranthene & $0.29 \pm 0.01^{\mathrm{b}}$ & $0.36 \pm 0.03^{b}$ & $0.42 \pm 0.04^{\mathrm{a}}$ & $*$ \\
\hline Benzo(a)pyrene & $0.48 \pm 0.03^{b}$ & $0.50 \pm 0.05^{b}$ & $0.62 \pm 0.07^{\mathrm{a}}$ & $*$ \\
\hline \multicolumn{5}{|c|}{ Ham } \\
\hline PAH $\left(\mu \mathrm{g} \cdot \mathrm{kg}^{-1}\right)$ & Boiling & Roasting & Curing & Significance \\
\hline Naphthalene & $6.81 \pm 0.39^{b}$ & $7.82 \pm 0.74^{b}$ & $10.45 \pm 0.78^{a}$ & $*$ \\
\hline Acenaphthene & $6.67 \pm 0.31^{\mathrm{c}}$ & $8.33 \pm 0.51^{\mathrm{b}}$ & $13.37 \pm 0.65^{\mathrm{a}}$ & $*$ \\
\hline Flourene & $9.78 \pm 0.41^{\mathrm{b}}$ & $10.52 \pm 0.83^{\mathrm{b}}$ & $12.85 \pm 0.17^{\mathrm{a}}$ & $*$ \\
\hline Phenanthrene & $25.20 \pm 1.33^{\mathrm{b}}$ & $34.64 \pm 1.58^{\mathrm{a}}$ & $35.42 \pm 1.18^{\mathrm{a}}$ & $*$ \\
\hline Anthracene & $0.45 \pm 0.04^{\mathrm{c}}$ & $0.66 \pm 0.06^{\mathrm{b}}$ & $0.83 \pm 0.05^{\mathrm{a}}$ & $*$ \\
\hline Fluoranthene & $2.99 \pm 0.19^{c}$ & $4.25 \pm 0.36^{\mathrm{b}}$ & $5.86 \pm 0.45^{\mathrm{a}}$ & $*$ \\
\hline Pyrene & $1.48 \pm 0.12^{\mathrm{c}}$ & $2.52 \pm 0.21^{\mathrm{b}}$ & $2.92 \pm 0.11^{\mathrm{a}}$ & $*$ \\
\hline Benzo(k)fluoranthene & $0.37 \pm 0.04$ & $0.38 \pm 0.03$ & $0.43 \pm 0.07$ & n.s \\
\hline Benzo(a)pyrene & $0.35 \pm 0.02^{\mathrm{b}}$ & $0.40 \pm 0.02^{\mathrm{a}}$ & $0.43 \pm 0.03^{\mathrm{a}}$ & $*$ \\
\hline \multicolumn{5}{|c|}{ Shoulders } \\
\hline PAH $\left(\mu \mathrm{g} \cdot \mathrm{kg}^{-1}\right)$ & Boiling & Roasting & Curing & Significance \\
\hline Naphthalene & $9.79 \pm 0.38$ & $9.81 \pm 0.32$ & $10.69 \pm 0.92$ & n.s. \\
\hline Acenaphthene & $8.59 \pm 0.47^{\mathrm{c}}$ & $9.65 \pm 0.63^{b}$ & $10.68 \pm 0.65^{a}$ & $*$ \\
\hline Flourene & $8.88 \pm 0.27^{\mathrm{c}}$ & $10.15 \pm 0.35^{\mathrm{b}}$ & $11.19 \pm 0.37^{\mathrm{a}}$ & $*$ \\
\hline Phenanthrene & $29.25 \pm 0.51^{\mathrm{c}}$ & $32.11 \pm 1.53^{\mathrm{b}}$ & $35.76 \pm 0.85^{\mathrm{a}}$ & $*$ \\
\hline Anthracene & $0.81 \pm 0.04^{\mathrm{b}}$ & $0.87 \pm 0.02 \mathrm{a}^{\mathrm{b}}$ & $0.92 \pm 0.04^{\mathrm{a}}$ & $*$ \\
\hline Fluoranthene & $4.80 \pm 0.21^{\mathrm{b}}$ & $5.12 \pm 0.17 \mathrm{a}^{\mathrm{b}}$ & $5.32 \pm 0.38^{\mathrm{a}}$ & $*$ \\
\hline Pyrene & $1.98 \pm 0.16^{\mathrm{c}}$ & $2.62 \pm 0.10^{\mathrm{b}}$ & $2.85 \pm 0.09^{\mathrm{a}}$ & $*$ \\
\hline Benzo(k)fluoranthene & $0.36 \pm 0.05$ & $0.39 \pm 0.03$ & $0.40 \pm 0.05$ & n.s. \\
\hline Benzo(a)pyrene & $0.50 \pm 0.06^{\mathrm{b}}$ & $0.56 \pm 0.04 \mathrm{a}^{\mathrm{b}}$ & $0.61 \pm 0.02^{\mathrm{a}}$ & $*$ \\
\hline \multicolumn{5}{|c|}{ Bacon } \\
\hline PAH $\left(\mu \mathrm{g} \cdot \mathrm{kg}^{-1}\right)$ & Boiling & Roasting & Curing & Significance \\
\hline Naphthalene & $8.78 \pm 0.94^{c}$ & $9.98 \pm 0.44^{\mathrm{b}}$ & $13.18 \pm 0.42^{\mathrm{a}}$ & $*$ \\
\hline Acenaphthene & $4.90 \pm 0.08^{c}$ & $7.90 \pm 0.19^{b}$ & $11.84 \pm 0.28^{\mathrm{a}}$ & $*$ \\
\hline Flourene & $6.17 \pm 0.31^{\mathrm{b}}$ & $6.83 \pm 0.28^{\mathrm{b}}$ & $8.66 \pm 0.76^{\mathrm{a}}$ & $*$ \\
\hline Phenanthrene & $26.88 \pm 1.12^{\mathrm{b}}$ & $33.40 \pm 1.45^{\mathrm{a}}$ & $35.40 \pm 1.51^{\mathrm{a}}$ & $*$ \\
\hline Anthracene & $0.70 \pm 0.09^{\mathrm{b}}$ & $0.86 \pm 0.03^{\mathrm{a}}$ & $0.92 \pm 0.04^{\mathrm{a}}$ & $*$ \\
\hline Fluoranthene & $4.02 \pm 0.20^{\mathrm{b}}$ & $5.95 \pm 0.08^{\mathrm{a}}$ & $6.39 \pm 0.53^{\mathrm{a}}$ & $*$ \\
\hline Pyrene & $1.66 \pm 0.17^{b}$ & $2.75 \pm 0.21^{\mathrm{a}}$ & $2.78 \pm 0.12^{\mathrm{a}}$ & $*$ \\
\hline Benzo(k)fluoranthene & $0.42 \pm 0.03^{\mathrm{c}}$ & $0.53 \pm 0.03^{\mathrm{b}}$ & $0.61 \pm 0.05^{\mathrm{a}}$ & $*$ \\
\hline Benzo(a)pyrene & $0.51 \pm 0.04^{b}$ & $0.53 \pm 0.03^{b}$ & $0.67 \pm 0.06^{\mathrm{a}}$ & $*$ \\
\hline
\end{tabular}

When boiling process was applied, acenaften had the highest value $\left(8.59 \pm 0.47 \mu \mathrm{g} \mathrm{kg}^{-1}\right)$ for jam compared to pork meat, shoulders and bacon (Table 1). For all samples analyzed (pork meat, shoulders, ham and bacon), acenaften had the lowest values when boiling process was applied, followed by roasting and curing processes. For all samples analyzed (pork meat, shoulders, ham and bacon), when curing process was applied, fluoranthene and pyrene had the highest values compared to roasting and boiling processes. Similar results were observed by Djinovic \& al [32], who reported the following values for PAHs: benzo(k)fluoranthene $0.64-31.54 \mu \mathrm{g} \mathrm{kg}^{-1}$, benzo(a)pyrene $0.07-7.04 \mu \mathrm{g} \mathrm{kg}^{-1}$. JIRA \& al [38] determined the quantity of smoked-PAHs with an average benzo(a)pyrene of $0.13 \mu \mathrm{g} \mathrm{kg}^{-1}$, benzo(a)anthracene $0.61 \mu \mathrm{g} \mathrm{kg}$, benzo(b)fluoranthene $0.21 \mu \mathrm{g} \mathrm{kg}^{-1}$. When the smoking process was carried out by different species of fish, applying different types of wood, sawdust or charcoal (SILVA \& al [33]) noted that sawdust generated the largest amount of PAHs.
In the case of bacon, naphthlate, acenaphthene and phenanthrene registered the lower values $(26.88 \pm 1.12$; $4.90 \pm 0.08$ and $8.78 \pm 0.94 \mu \mathrm{g} \mathrm{kg}^{-1}$ ) when boiling process was applied. For the same PAHs applying curing process, the highest values were found. The others PAHs for bacon followed the same trend as naphthlate, acenaphthene and phenanthrene. In bacon, all PAHs have had high values compared to hydrocarbon of pork meat, shoulders and jam, regardless what kind of thermal processes was applied. Various studies had an aim to melt the fat through the pyrolysis process and how to accumulate PAHs, the influence of high temperatures and the formation of PAHs. A study on duck chest PAHs subjected to thermal treatments over different time periods showed that the skinless, carbonprepared grill samples had a level of $320 \mu \mathrm{g} \mathrm{kg}^{-1}$, those made with skin, in the same way, showed a concentration of $300 \mu \mathrm{g} \cdot \mathrm{kg}^{-1}$; samples prepared by smoking had $210 \mu \mathrm{g} \mathrm{kg}-1$, and with liquid smoke $0.3 \mu \mathrm{g} \mathrm{kg}^{-1}$ (CHEN \& al [39]; LIJINSKI \& al [40, 41]; STALL \& al [42]). 
The thermal process and fat content influence the assimilation of PAHs into the product. In a study by (SALEH \& al [43]) on meat and fish, using two types of gas grills with different shapes (horizontally and vertically), they observed that the cooked meat on the vertical grate does not allow the leakage of the fat to the heat source and the level of PAHs was 30 times smaller than when meat was processed on the horizontal grate. HITZEL \& al [35] studied the content of PAHs and phenolic substances in cured mini salami. Different types of wood and wood mixed with spices were used. Walnut and poplar wood reduced by $35-55 \%$ the content of PAHs compared to beech wood, which is very often used. Using softwood or poplar wood in order to perform curing process can obtain low PAHs content (HITZEL \& al [44]).

Cooking processes such as frying, curing, steam cooking, charcoal grilling or liquid smoking are related to the formation of PAHs. A product prepared by curing process during three hours recorded higher values of PAHs compared to other types of preparation (e.g. frying, steam cooking) (CHEN \& al [39]; CHEN \& al [34]). ABDUL \& al [37] observed an increase in PAHs for: naphthalene, 2 methylnaphthalene, acenaphthalene, phenanthrene, anthracene and fluoranthene, when curing process for meat was applied. Also, OLATUNJI \& al [36], observed that the values of benzo(k)fluoranthene, benzo(a)pyrene, indeno (1,2,3-cd)perylene increased when curing process was applied.

Also, PAHs are present in other products such as potatoes, cooked fish, eggs and various fruit drinks. Persons who consume daily this kind of food can ingest about $3 \mu \mathrm{g}$ of PAHs. This is a very high amount compared to the concentration that people can breathe to the air, althought in air the concentration of PAHs is about $370 \mathrm{ng}$ day $^{-1}$. Foods subjected to any heat treatment: boiling, roasting, curing increases the content of PAHs in the diet of any consumer (LODOVICI \& al [45]; SALEH \& al [43]).

The content of PAHs in different types of products (variable foreign fat content, different types of membrane, natural or artificial) depend on the temperature generated by the smoke of wood burned (JIRA \& al [38]). Thus, a sawdust firing temperature below $600^{\circ} \mathrm{C}$ is believed to be indicated for a reduced PAH content, but not less than $500^{\circ} \mathrm{C}$, in order not to prolong the curing time. PAHs that are formed in foods, which are preparated by coal grill, depend on: the level or amount of fat the food or the meat contains, temperature and cooking time or processing time. In food, during processing and preparation, PAHs can be formed by various methods: use of the grill, use of smoke, drying, roasting, baking or roasting (SALEH \& al [43]).

Some PAHs are considered to be genotoxic carcinogens for human health. These PAHs present a risk regardless of the dose at which we are exposed, and cannot be identified a minimum level of safety (European Communities 2001 [46]). Although food can be contaminated from various sources with PAHs, the level of PAHs increases significantly in processed or cooked foods by boiling, roasting and smoking (European Communities 2001; FARHADIAN \& al [47]; US EPA 1984 [48]). The content of PAHs in the analyzed products depends on: the consistency of the analyzed product, fat content, type of thermal treatment applied, and the specificity of each hydrocarbon.

\section{Conclusions}

In the present study, the highest values were found for the following PAHs: phenanthrene, naphthalenes, flourene, acenaphthene. While the lowest values were observed in: benzo(a)pyrene, benzo(k)fluoranthene and anthracene. Thermal process (boiling, roasting, curing) and anatomical portion had influence in the level of PAHs assimilated in each product. The highest values of PAHs were observed in curing process compared to roasting and boiling.

\section{References}

1. C. VINTILĂ, Tehnologia prelucrarii cărnii de calitate, Editura Waldpress, pp. 6-7:54-55 (2008).

2. A. COROIAN, Toxicologia alimentelor. Editura Bioflux, Cluj-Napoca (2013).

3. R. SUHAROSCHI, Toxicologia alimentelor. Ed. Academic Pres, Cluj-Napoca, pp. 269-272 (2013).

4. C. RĂDUCU, A. COROIAN, Biotehnologii de prelucrare şi control a calităţii produselor vegetale şi animale. Editura AcademicPres, Cluj-Napoca (2016).

5. I. OȚEL, Tehnologia produselor din carne, Editura Tehnică, 14-18 (1979).

6. M. BULANCEA, G. RÂPEANU, Autentificarea şi identificarea falsificărilor produselor alimentare. Editura Didactică şi Pedagogică Bucureşti, 2009.

7. G. GRIMMER, Carcinogenic hydrocarbons in the human environment. Dtsch Apoth Ztg 108, 529 (1968).

8. T. NIELSEN, H.E. JORGENSEN, J.C. LARSEN, M. POULSEN, City air pollution of polycyclic aromatic hydrocarbons and other mutagens: occurrence, sources and health effects, Sci. Tot. Environ., 189/190, 41-49 (1996).

9. J.C. FETZER, The Chemistry and Analysis of the Large Polycyclic Aromatic Hydrocarbons, Polycyclic Aromatic Compounds (New York: Wiley) 27(2), pp. 143 (2000).

10. I. STUMPE-VIKSNA, V. BARTKEVICS, A. KUKARE \& A. MOROZOVS, Polycyclic aromatic hydrocarbons in meat smoked with different types of wood. Food Chemistry 110, 794-797 (2008).

11. EC (2005). Commission recommendation of 4 February 2005 on the further investigation into the levels of polycyclic aromatic hydrocarbons in certain foods. Official Journal of the European Union, L, 34, 43-45.

12. C. BANU, Suveranitate, securitate şi siguranţă alimentare, Editura ASAB, Bucureşti (2007).

13. C. LASLO, G. ŞTEŢCA, R. SUHAROSCHI, C. MUREŞAN, Controlul calităţii şi igiena produselor alimentare de origine animală, Editura Risoprint, Cluj-Napoca, pp. 28-30 (2008).

14. T. SHIBAMOTO, F.L. BJELDANES, Introduction to Food Toxicology, Ed. Academic Press/Elsevier (2009).

15. K. SKUPINSKA, I. MISIEWICZ, T. KASPRZYCKAGUTTMAN, Polycyclic aromatic hydrocarbons: physiochemical properties, environmental appearance and impact on living organisms. Acta Pol Pharm 61(3), 233240 (2004).

16. J. LEWTAS, D. WALSH, R. WILLIAMS, L. DOBIAS, Air pollution exposure DNA adduct dosimetry in humans and rodents: evidence for non-linearity at high doses. Mut Res 378(1-2), 51-63 (1997). 
17. D. PHILLIPS, Polyciclic aromatic hydrocarbons in the diet, Mutation Research/Genetic Toxicology and Enviromental Mutagenesis, 443, 139-147 (1999).

18. IARC. (2010). Monographs on the evaluation of carcinogenic risks to humans (vol. 92). Lyon, France: International Agency for Research on Cancer.

19. EFSA. (2008a). Scientific opinion of the panel on contaminants in the food chain on a request from the European Commission on polycyclic aromatic hydrocarbons in food. EFSA Journal, 724, 1-114.

20. J.W. HOWARD, T. FAZIO, Analytical methodology and reported findings of polycyclic aromatic hydrocarbons in foods, Journal Association of Official Analytical Chemists, 63, 1077-1104 (1980).

21. C.A. MENZIE, B.B. POTOCKI, J. SANTODONATO, Exposure to carcinogenic PAHs in the environment. Environ. Sci. Technol. 26, 1278-83 (1992).

22. L.M. SHABAD, Y.L. COHAN, Contents of benzo[a]pyrene in some crops. Arch Geschwulstforsch 40, 237243 (1972).

23. IARC (1987). Monographs on the evaluation of the carcinogenic risk of chemicals to humans. Overall evaluation of carcinogenity: An updating of IARC monographs (vols. 1-42). Lyon, France: International Agency for Research on Cancer, Supplement 7.

24. M. JÄGERSTAD, K. SKOG, Genotoxicity of heatprocessed foods, Mutation Research 574, 156-172 (2005).

25. M. PÖHLMANN, A. HITZEL, F. SCHWÄGELE, K. SPEER \& W. JIRA, Contents of polycyclic aromatic hydrocarbons (PAH) and phenolic substances in Frankfurter-type sausages depending on smoking conditions using glowmoke. Meat Science, 90, 176-184 (2012).

26. P.S. DASGUPTA, T. LAHIRI, Alteration of brain catecholamines during growth of benzo[a]pyrene induced murine fibrosarcoma. Neoplasm 39(3), 163-175 (1992).

27. A. SZCZEKLIK, J. SZCZEKLIK, Z. GALUSZCKA, J. MUSIAL, E. KOLARZYK, D. TARQOSZ, Humoral immunosuppression in men exposed to polycyclic aromatic hydrocarbons and related carcinogens in polluted environments. Environ Health Perspect, 102(3), 302-314 (1994).

28. X.L. ZHAO, Effects of benzo(a)pyrene on the humoral immunity of mice exposed by single intraperitoneal injection. Chin J Prevent Med, 24(4), 220-232 (1990).

29. T. NORAT, S. BINGHAM, P. FERRARI, Meat, fish and colorectal cancer risk: the European prospective investigation into cancer and nutrition, Journal of the National Cancer Institute 97, 907-916 (2005).

30. H. KNUTSEN, M.-L. BINDERUP, R. VIKSE, S. $\varnothing$ VREB $\varnothing$, Vurdering af helserisiko ved konsum av grillet mat. Norges Vitenskapskomiteen for Mattrygghet (VKM), Norweigen, English summary (2007).

31. M. CIECIERSKA, M. OBIEDZIŃSKI, Influence of Smoking Process on Polycyclic Aromatic Hydrocarbons Content in Meat Products, Acta Sci. Pol., Technol. Aliment. 6(4), 17-28 (2007).

32. J. DJINOVIC, A. POPOVIC, W. JIRA, Polycyclic aromatic hydrocarbons (PAHs) in different types of smoked meat products from Serbia. Meat Science, volume 80, Issue 2, pp. 449-456 (2008).

33. B.O. SILVA, O.T. ADETUNDE, T.O. OLUSEYI, K.O. OLAYINKA, B.I. ALO, Effects of the methods of smoking on the levels of polycyclic aromatic hydrocarbons (PAHs) in some locally consumed fishes in Nigeria. African Journal of Food Science, vol. 5(7), 384-391 (2011).

34. G. CHEN, H. SONG, C. MA, Aroma-active compounds of Beijing roast Duck. Flavour Fragrance J., 24, 186-191 (2009).

35. A. HITZEL, M. POHLMANN, F. SCHWAGELE, K. SPEER, W. JIRA, Polycyclic aromatic hydrocarbons (PAH) and phenolic substances in meat products smoked with different types of wood and smoking spices. Food Chemistry, volume 139, Issues 1-4, 955-962 (2013).

36. O.S. OLATUNJI, O.S. FATOKI, B.O. OPEOLU, B.J. XIMBA, Determination of polycyclic aromatic hydrocarbons [PAHs] in processed meat products using gas chromatography - Flame ionization detector. Food Chemistry, volume 156, 296-300 (2014)

37. I.W. ABDUL, M.O. AMOAMAH, A. ABDALLAH, Determinants of polycyclic aromatic hydrocarbons in smoked bushmeat. International Journal of Nutrition and Food Sciences 3(1), 1-6 (2013).

38. W. JIRA, M. PÖHLMANN, A. HITZEL, F. SCHWÄGELE, Smoked meat products - innovative strategies for reduction of polycyclic aromatic hydrocarbons by optimisation of the smoking process. International $57^{\text {th }}$ Meat Industry Conference, Belgrade, Serbia (2013).

39. B.H. CHEN, Y.S. LIN, Formation of polycyclic aromatic hydrocarbons during processing of duck meat. J Agric Food Chem 45, 1394-1403 (1997).

40. W. LIJINSKI, P. SHUBIK, Polynuclear Hydrocarbon Carcinogens in Cooked Meat and Smoked Foods, Ind Med Surg 34, 152-154 (1965).

41. W. LIJINSKI, A.E. ROSS, Production of Carcinogenic Polynuclear Hydrocarbons in the Cooking of Food, Food Cosmet Toxicol 5, 343-347 (1967).

42. W. STALL, G. EISENBRAND, Determination of polynuclear aromatic hydrocarbons and nitrosamines, HPLC in food analysis, Academic Pres, New York, pp. 377-408 (1988).

43. A. SALEH, Y. YAMINI, M. FARAJI, M. REZAEE, M. CHAMBARIN, Ultrasound-assisted emulsification microextraction method based on applyng low density organic solvent folloved by gas cromatography analysis for the determination of polycyclic aromatic hydrocarbons in water samples, Journal of Chromatography A, volume 1216, Issue 39, 6673-6679 (2009).

44. A. HITZEL, M. PÖHLMANN, F. SCHWÄGELE, K. SPEER \& W. JIRA, Polycyclic aromatic hydrocarbons (PAH) and phenolic substances in cold smoked sausages depending on smoking conditions using smouldering smoke. Journal of Food Research 1, 45-59. (2012).

45. M. LODOVICI, P. DOLARA, C. CASALINI, S. CIAPPELLANO, G. TESTOLIN, Polycyclic aromatic hydrocarbon contamination in the italian diet, Food Additives \& Contaminants, 12, 703-713 (1995).

46. EC (European Communities), Ambient Air Pollution by Polycyclic Aromatin Hydrocarbons (PAH) - Position Paper Annexes, (preparedby the Working 70 Group On Polycyclic Aromatic Hydrocarbons). (2001).

47. A. FARHADIAN, S. JINAP, A. FARIDAH, Z.I. SAKAR, Determination of polycyclic aromatic hydrocarbons in grilled meat, Food Control, volume 21, Issue 5, pp. 606610 (2010).

48. US EPA, Review and evaluation of the evidence for cancer associated with air pollution. EPA 450/5-83-006R, U.S. Environmental Protection Agency, Arlington (1984). 